\title{
Electrochemical Determination of Trichloroacetic Acid using Platinum Electrode
}

\author{
M. Khodari ${ }^{1 *}$, A. A. Abd-Elrady ${ }^{2}$, E.M. Rabie ${ }^{3}$, H.F. Assaf ${ }^{4}$ \\ ${ }^{1}$ Professor of analytical chemistry, Chemistry department, Faculty of science, South valley university, Qena, \\ 83523, Egypt. \\ khodari@svu.edu.eg \\ ${ }^{2}$ lectural of analytical chemistry, Chemistry department, Faculty of science, South valley university, Qena, \\ 83523, Egypt. \\ ahmedchem@yahoo.com \\ ${ }^{3}$ lectural of analytical chemistry, Chemistry department, Faculty of science, South valley university, Qena, \\ 83523, Egypt. \\ Emr_chem@yahoo.com \\ ${ }^{4}$ Teaching assistant of analytical chemistry, Chemistry department, Faculty of science, South valley \\ university, Qena, 83523, Egypt
}

Elprof_3ssaf@yahoo.com

\section{ABSTRACT}

The electrochemical reduction of Trichloroacetic acid (TCA) on a platinum electrode by cyclic and linear sweep voltammetry was described. The measurements were investigated under optimized conditions. The supporting electrolyte was $0.01 \mathrm{M}$ sodiumnitrate solution $(\mathrm{pH} 6.0)$, scan rate $50 \mathrm{mV} \backslash \mathrm{s}$ and the reached detection and quantification limits was $4 \times 10^{-6} \mathrm{~mol} \mathrm{I}^{-1}$. The obtained result indicated linear increasing of the current with concentration of TCAA between lower and upper detection limits and excellent sensitivity towards TCAA reduction, which demonstrates the analytical utility of platinum electrode. Meanwhile, interference from other ions and substances were examined. The experimental results indicate that the method for the determination of TCAA samples is successful comparing with other methods or techniques.

\section{Keywords}

Trichloroacetic acid; cyclic and linear sweep voltammetry.

\section{Academic Discipline And Sub-Disciplines}

Chemistry; Analytical chemistry.

\section{SUBJECT CLASSIFICATION}

Applied Chemistry; Electroanalytical Chemistry.

\section{TYPE (METHOD/APPROACH)}

Organo-halid compounds such as trichloroacetic acid (TCAA) is produced as byproducts of water chlorination. Detection and determination of trichloroacetic acid are performed by linear and cyclic sweep voltammetry on a platinum electrode under optimized conditions and finally providing an easy, cheap, available, accurate,sensitive and with good reproducibility.

\section{Council for Innovative Research}

Peer Review Research Publishing System

Journal: Journal of Advances in Chemistry

Vol. 9, No. 2

editorjaconline@gmail.com

www.cirworld.org/journals 


\section{1-INTRODUCTION}

Trichloroacetic acid (TCAA), as an organohalide pollutant, is found in industrial wastes and as byproducts of water chlorination ${ }^{(1-4)}$. The process used for disinfecting drinking water to control infectious microbial contaminants ${ }^{(5-8)}$.It can introduced also through pesticide degradation, atmospheric degradation of refrigerant compounds ${ }^{(9)}$.(TCAA) is highly soluble in water and toxic to humans, animals, plants and algae, Morever trichloroacetic acid has been used as a herbicide $^{(5)}$. It is of great concern to public health because of their suspected carcinogenicity which exhibit a potential risk of cancer after a lifetime exposure in drinking water at low concentrations ${ }^{\left({ }^{8}\right)}$, mutagenicity as well as developmental, reproductive, hepatic toxicity and it can cause Irritation of the skin and eyes, risk of breath defects, irritate nose and lung causing coughing or shortness of breath. Also it may affect kidney, and the US Environmental Protection Agency (EPA) has classified them as probable human carcinogens ${ }^{(5-7)}$. (TCAA) is regularly found in drinking water from drinking water treatment plants in the $\mathrm{mg} / \mathrm{l}$ range, but also in environmental waters such as surface water, rainwater precipitation, seawater and wastewaters. They also have been recently detected in swimming pools and tap water ${ }^{(1,5-8)}$.So a large number of techniques have been suggested for the treatment of drinking water containing TCAA among which are gas chromatography (GC) with an electron capture detector (ECD) , GC with ECD and mass spectrometric (MS), and HPLC technique ${ }^{(5)}$. Unfortunately these methods required tedious and labor intensive derivatization procedure and the accepted treatment technologies of drinking water, e.g., adsorption by activated carbon, may not perform well with TCAA due to their very high hydrophilicity ${ }^{(4,10)}$ finally others techniques have been suggested for the treatment of drinking water containing TCAA, among which are biodegradation, photolysis assisted with ultrasound or microwave and reductive processes using zero valent iron or iron-based bimetal. Unfortunately, these techniques are difficult to adopt for the practical disposal of TCAA, in the coming years, due to their respective drawbacks (high expense or poor dechlorination efficiency) ${ }^{(9)}$.Biodegradation is not a perfect method for the treatment of drinking water, considering new pollution brought by the added nutrients, electron donor and microorganisms. Compared with the above methods, the electrochemical methods appears to achieve the goal ${ }^{(4,9-10)}$ due to intrinsically milder, more efficient, rabid, reliable, economize, with high selectivity and sensitivity for the detection of TCAA that is make the electrochemical method more likely to be employed for the treatment of drinking water containing TCAA ${ }^{(9)}$. Electroanalytical methods based on reductive dehalogenation of TCAA $^{(9)}$ in acid medium at $\mathrm{pH}>7$. They stated that the stationary reduction processes resulting in the splitting of the carbon-halogen bond take on the scale without forming toxic compounds ${ }^{(9)}$. Acetic acid was observed in the course of the reduction of halogenated of acetic acids contaiining Trichloroacetic acid to safe acetic acid and the mechanism expected is $(\mathrm{TCA}) \rightarrow(\mathrm{DCA}) \rightarrow(\mathrm{MCA}) \rightarrow$ acetic acid $^{(4,9-12)}$. Our work is aimed to Determination of the desirable compounds quantitatively and studying the effect of some parameters on the peak's height such as Supporting Electrolyte, Deposition Time, Scan Rate, $\mathrm{pH}$ and concentration to achieve the ideal conditions. The work is designed to determine the concentration of (HAAs) at low concentration as possible and finally providing an easy, cheap, available, accurate and with good reproducibility. In the present paper, the electrocatalytic reduction of TCA at platinum electrode using cyclic and linear sweep voltammetric technique under the optimum conditions sush as supporting electrolyte, concentration of supporting electrolyte, scan rate, accumulation potential, and deposition time to determine TCAA with high selectivity and Sensitive method in presence of interferences with lower detection limit than other methods with the same and different techniques.

\section{2-EXPERIMENTAL}

\subsection{Chemicals and solutions}

Pure trichloroactic acid was obtained from oxford laboratory chemicals. A stock solution $1 \times 10^{-2} \mathrm{M}$ of Trichloroactic acid was daily prepared by dissolving $0.1635 \mathrm{gm}$ of this acid in doubly distilled water. Solutions of different concentrations were prepared by suitable dilution from the stock solution, sodium nitrate $(\mathrm{BDH}) 0.1 \mathrm{M}$ as (supporting electrolyte) was prepared by direct weighing of the required amount of this salt in the bidistilled water (dissolving $2.124 \mathrm{gm}$ of this salt in $250 \mathrm{ml}$ bidistilled water) and sodium hydroxide (BDH) 1:1 solution (50 gm / $50 \mathrm{ml} \mathrm{H2O}$ ) was prepared and well stored in a polypropylene container for some days to obtain a carbonate free solution. The required molarity was prepared by dilution from such solution then standardized using standard hydrochloric acid and to adjust he $\mathrm{pH}$ value.

\subsection{INSTRUMENTATION}

\subsubsection{Apparatus and cell}

A computer-aided electrochemistry system was used in the voltammetric studies. The system consists of the following:

A potentiostat model 263 (EG\& G PARC) Princeton applied corporation (made in USA), 305 magnetic stirrer (PARC).

Electroanalytical software model 270 / 250 version 4.0 (PARC) which control the potentiostat via IEEE 488 GPIB using IBM compatible 386 with VGA monitor and HP Laser Jet $4 \mathrm{~L}$ printer. The characteristic of modern stripping analyzer potentiostat control of working electrode, which minimize errors from the cell resistance (distorted voltammogram with decreased peak current and shifted and broadened peaks). This is accomplished with a three-electrode system, the working electrode which is Pt electrode, the reference electrode $(\mathrm{Ag} / \mathrm{AgCl})$ and a Pt wire as a counter.

\section{RESULTS AND DISSCUTIONS}

Both cyclic and linear sweep voltammetric technique were used to determine trichloroacetic acid using platinum electrode after optimizing the conditions. The reduction peak was used to determine trichloroacetic acid and the effect of various parameters such as supporting electrolyte, $\mathrm{pH}$ value, deposition potential, scan rate and other variables were 
examined to select the suitable conditions for the determination of trichloroacetic acid. The cyclic voltammetric of trichloroacetic in $0.01 \mathrm{~mol} \mathrm{dm}^{-3}$ sodium nitrate as supporting electrolyte acid and $(\mathrm{pH}=6.0)$ showed a one reduction peak at $(130 \mathrm{mV})$ at $1 \times 10^{-4} \mathrm{~mol} \mathrm{dm}^{-3}$ of trichloroacetic acid vs. Ag/AgCl using $50 \mathrm{mV} / \mathrm{s}$ scan rate. Which attribute to trichloroacetic acid undergo reductive dehalogenation in electrochemical controlled condition according to these equations from $(1-7)^{(4,9-12)}$

$\begin{array}{lllllllll}\mathrm{Cl}_{3} \mathrm{C}_{2} \mathrm{OOH} & + & \mathrm{H}_{2} \mathrm{O} & \leftrightarrow & \mathrm{Cl}_{3} \mathrm{C}_{2} \mathrm{OO}^{-} & + & \mathrm{H}_{3} \mathrm{O}^{+} & 1 \\ \mathrm{Cl}_{3} \mathrm{C}_{2} \mathrm{OO}^{-} & + & 2 \mathrm{e} & \leftrightarrow & \mathrm{Cl}_{2} \mathrm{C}_{2} \mathrm{OO}^{--} & + & \mathrm{Cl}^{-} & 2 \\ \mathrm{Cl}_{2} \mathrm{HC}_{2} \mathrm{OO}^{--} & + & \mathrm{H}^{+} & \leftrightarrow & \mathrm{Cl}_{2} \mathrm{HC}_{2} \mathrm{OO}^{-} & & & \\ \mathrm{Cl}_{2} \mathrm{HC}_{2} \mathrm{OO}^{-} & + & 2 \mathrm{e} & \leftrightarrow & \mathrm{ClHC}_{2} \mathrm{OO}^{--} & + & \mathrm{Cl}^{-} & 4 \\ \mathrm{ClHC}_{2} \mathrm{OO}^{--} & + & \mathrm{H}^{+} & \leftrightarrow & \mathrm{ClH}_{2} \mathrm{C}_{2} \mathrm{OO}^{-} & & & \\ \mathrm{ClH}_{2} \mathrm{C}_{2} \mathrm{OO}^{-} & + & 2 \mathrm{e} & \leftrightarrow & \mathrm{H}_{2} \mathrm{C}_{2} \mathrm{OO}^{-} & & & \\ \mathrm{H}_{2} \mathrm{C}_{2} \mathrm{OO}^{--} & + & \mathrm{H}^{+} & \leftrightarrow & \mathrm{H}_{3} \mathrm{C}_{2} \mathrm{OO}^{-} & & \mathrm{Cl}^{-} & 6\end{array}$

Scheme1 illustration of the electro-dechlorination process. $\mathrm{RCl}$ : chloroacetic acids; $\mathrm{RH}$ : the dechlorinated product of chlorinated acids.

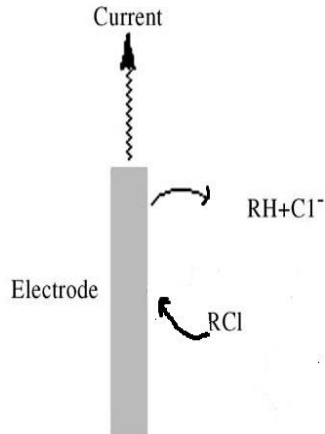

"Scheme 1"

"Figure.1" shows one reduction peak for cyclic voltammogram of $4 \times 10^{-4} \mathrm{~mol} \mathrm{dm}^{-3}$ trichloroacetic acid.

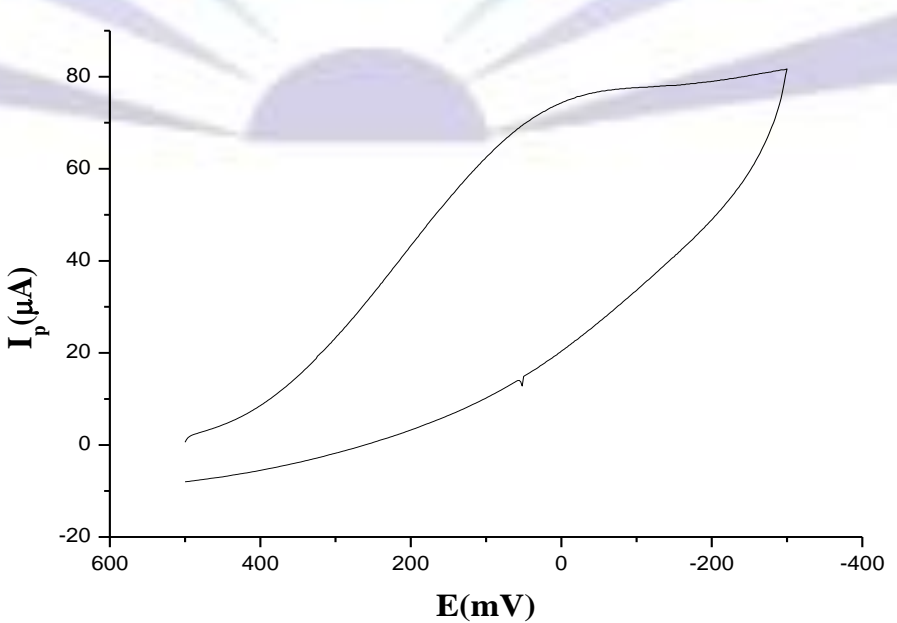

Fig.1: Cyclic voltammogram of $6 \times 10^{-4} \mathrm{~mol} \mathrm{dm}^{-3}$ trichloroacetic acid in $0.01 \mathrm{M}$ sodium nitrate $(\mathrm{pH}=6.0)$ at scan rate $50 \mathrm{mV} / \mathrm{s}$ using pt electrode. 


\subsection{Influence of The Supporting Electrolyte And Its Ionic Strength}

:Figure 2" Showed the influence of the supporting electrolyte on the reduction peak current of trichloroacetic acid was tested using different electrolytes. These electrolytes include: sodium phosphate, sodium nitrate, Britton-Robison buffer, sodium sulphate, sodium chloride, potassium chloride, acetate buffer disodium phosphate and trisodium phosphate.

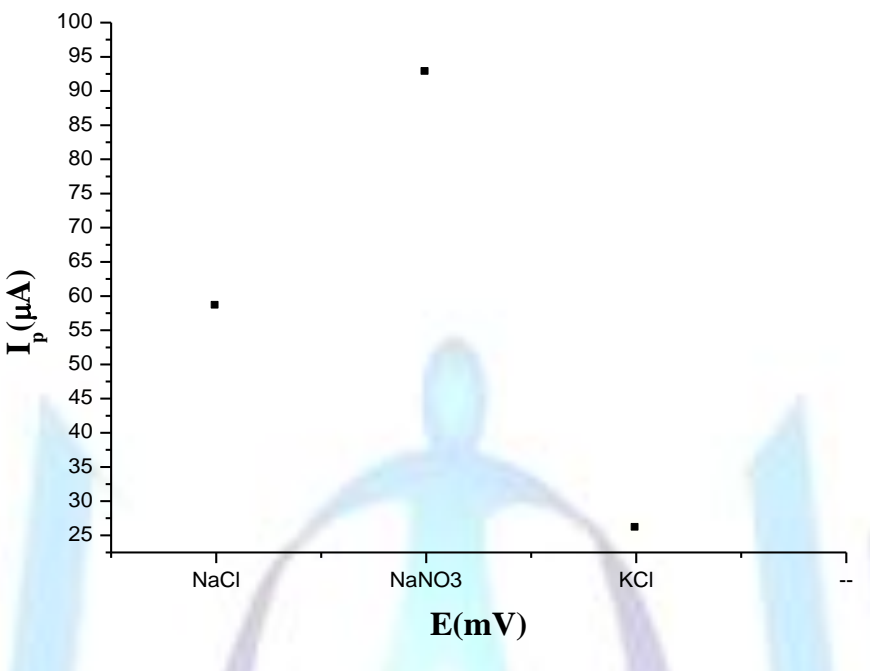

Fig. 2: Dependence of the peak current of $4 \times 10^{-4} \mathrm{~mol} \mathrm{dm}^{-3}$ trichloroacetic acid on the supporting electrolyte kind at $(\mathrm{pH}=6.0)$ using Pt electrode at scan rate $50 \mathrm{mV} / \mathrm{s}$.

The height and the shape of the peak were taken into consideration on choosing the suitable supporting electrolyte. The results showed that the reduction of trichloroacetic acid in sodium nitrate gave the best peak response.

"Figure 3" Showed that the effect of ionic strength of sodium nitrate on the peak response was investigated over the concentrations $(0.05,0.01,0.1,0.2$ and $0.5 \mathrm{M})$. It was found that the highest peak current value was found at concentration $0.01 \mathrm{M}$. So for our work, the concentration $0.01 \mathrm{M}$ of sodium nitrate was selected.

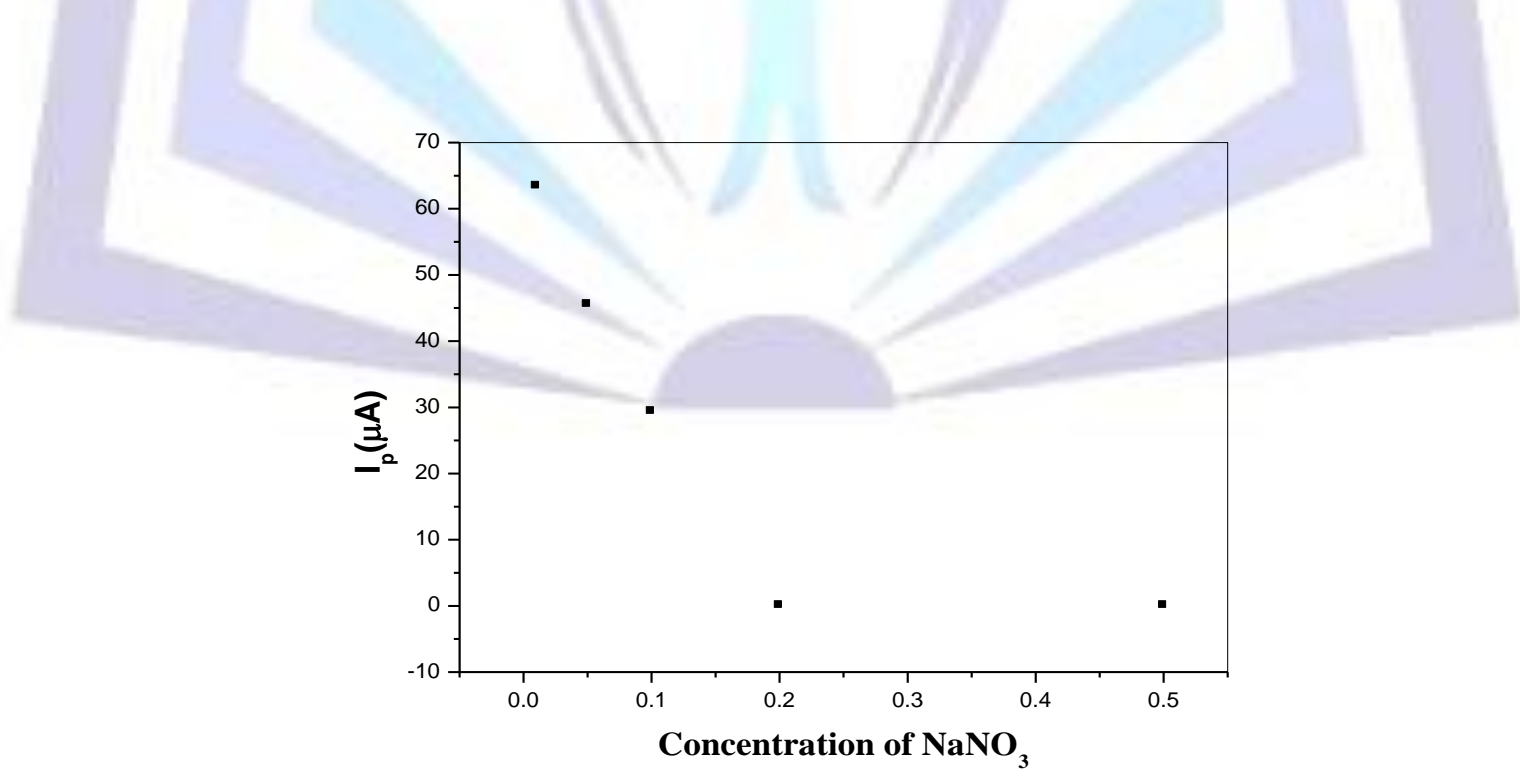

Fig.3: Dependence of the peak current of $4 \times 10^{-4} \mathrm{~mol} \mathrm{dm}^{-3}$ trichloroacetic acid on the concentration of the supporting electrolyte at $(\mathrm{pH}=6.0)$ using Pt electrode at scan rate $50 \mathrm{mV} / \mathrm{s}$. 


\subsection{Influence of $\mathrm{pH}$ of The Supporting Electrolyte}

"Figure 4" Illustrated the influence of $\mathrm{pH}$ of the supporting electrolyte solution (sodium nitrate) on the peak current of the reduction of the examined compound was studied over the range from 2.0 to 12 . The results showed that, the best peak shape and highest current was obtained at $\mathrm{pH}$ value equal 6 . Also, results illustrated that the peak was disappeared at $\mathrm{pH}$ 2 and 12.

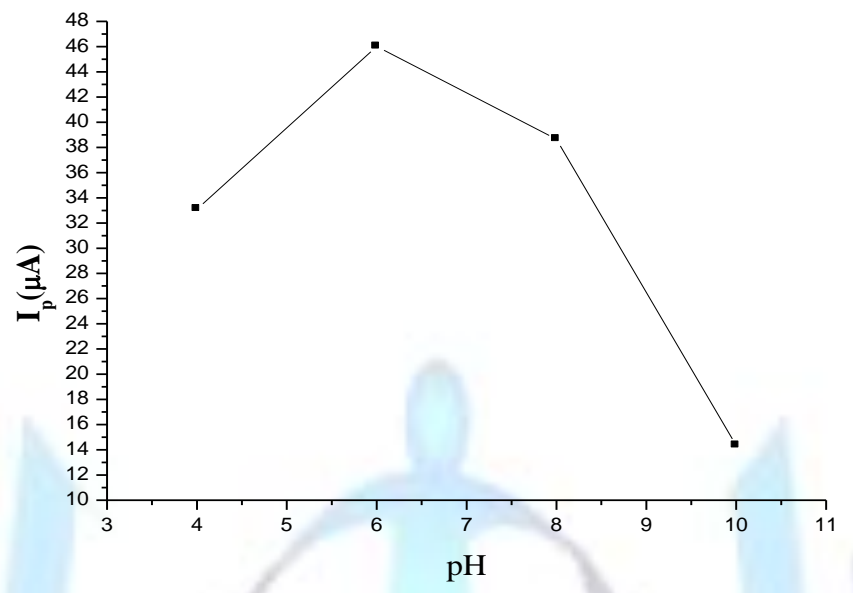

Fig. 4: Dependence of the peak current of $4 \times 10^{-4} \mathrm{~mol} \mathrm{dm}^{-3}$ trichloroacetic acid on $\mathrm{pH}$ of the supporting electrolyte.

On the other hand, "Figure 5" demonstrates that the peak potential shifted to more negative values by increasing the $\mathrm{pH}$ value.

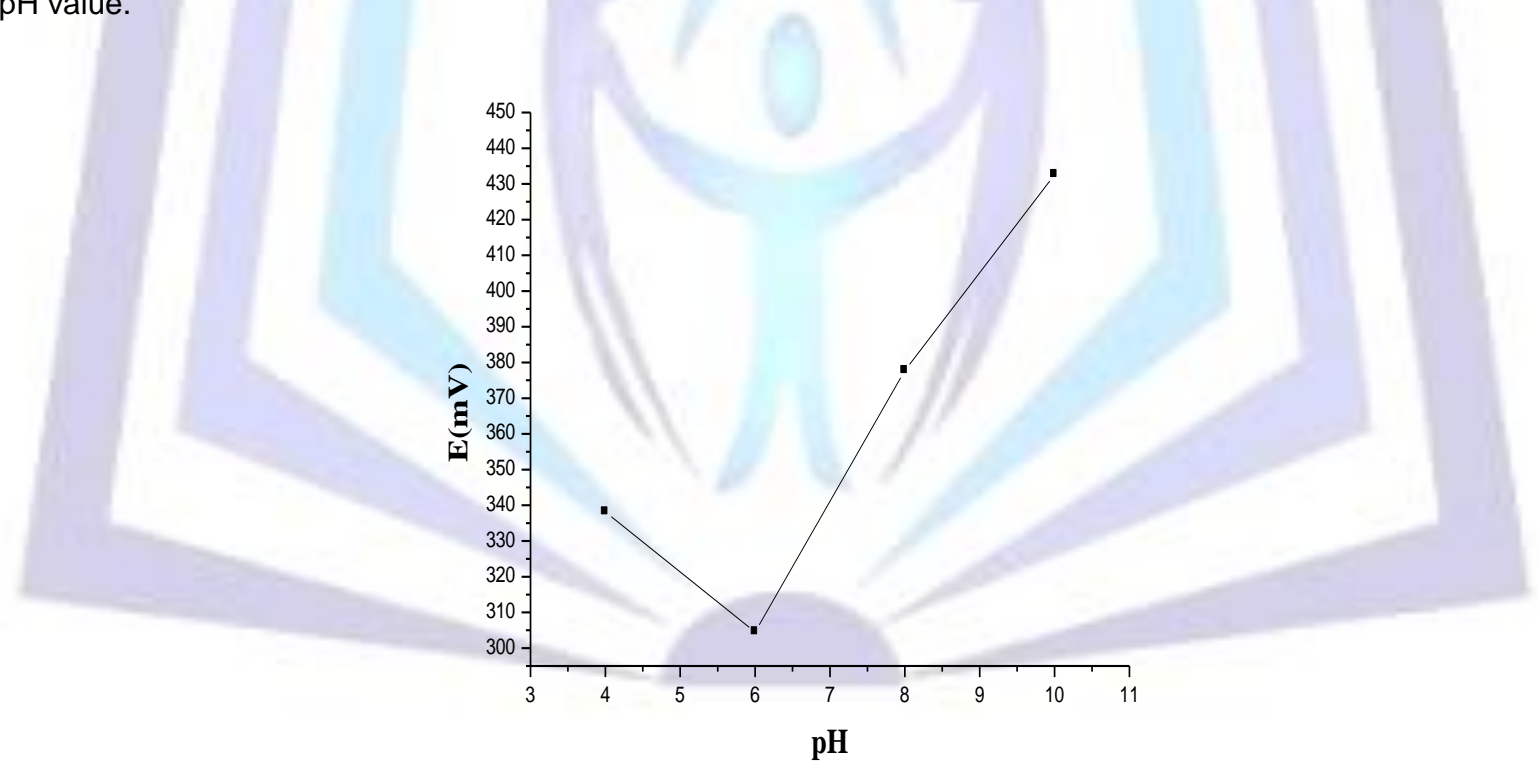

Fig.5: Dependence of the peak potential of $4 \times 10^{-4} \mathrm{~mol} \mathrm{dm}^{-3}$ trichloroacetic acid on $\mathrm{pH}$ of the supporting electrolyte

\subsection{Influence of scan rate}

"Figure5" showed the influence of the scan rate on the peak current of $2 \times 10^{-4} \mathrm{~mol} \mathrm{dm}^{-3}$ trichloroacetic in sodium nitrate $(\mathrm{pH}=6.0)$ was studied over the range 5 to $300 \mathrm{mV} / \mathrm{s}$. It was found that the peak current increases by increasing the scan rate, but at scan rate more than $100 \mathrm{mV} / \mathrm{s}$ the peak shape was distorted. The scan rate of $50 \mathrm{mV} / \mathrm{s}$ was selected for further work to avoid the distortion of the peak at higher concentrations of the acid. 


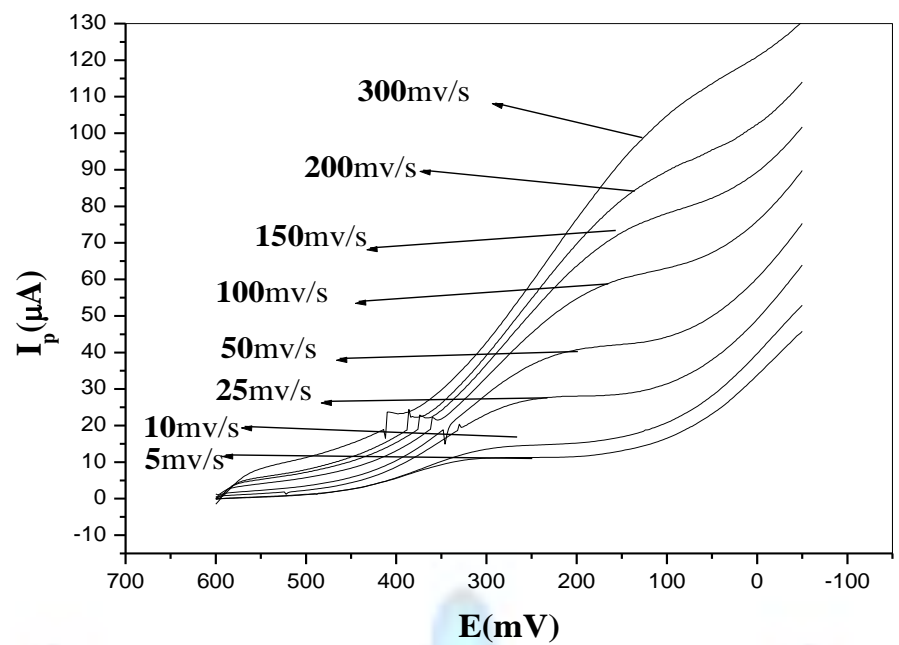

Fig.5: Voltammograms of $\left(2 \times 10^{-4}\right) \mathrm{mol} \mathrm{dm}^{-3}$ trichloroacetic acid at different scan rate, using Pt electrode sodium nitrate $(\mathrm{pH}=6.0)$.

While "figure 6" shows the effect of varying scan rate on peak current Ip of trichloroacetic acid. It was observed that the peak current increased by increasing scan rate.

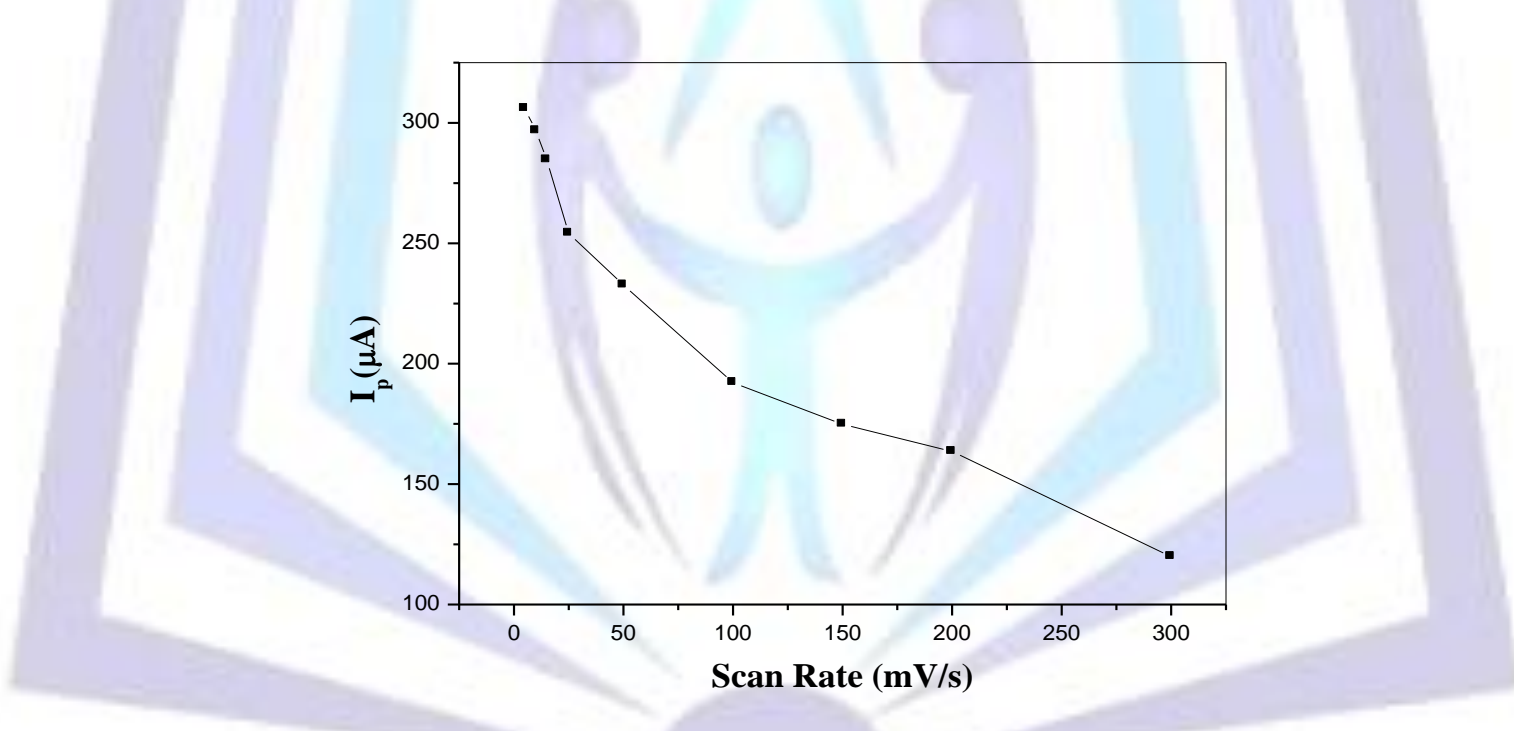

Fig. 6: Dependence of the peak current of $2 \times 10^{-4} \mathrm{~mol} \mathrm{dm}^{-3}$ trichloroacetic acid on the scan rate in sodium nitrate (pH=6.0) using pt electrode.

On plotting Log Ip (Logarithm peak current) vs. Log (Logarithm of scan rate) for $2 \times 10^{-4} \mathrm{~mol} \mathrm{dm}^{-3}$ trichloroacetic acid, a linear relation was observed over the range $5 \mathrm{mV} / \mathrm{s}$ to $300 \mathrm{mV} / \mathrm{s}$. with correlation coefficient 0.98 and standard deviation 0.0386 as seen in "figure 7 " These values are in close agreement with that expected for ideal reaction of the surface species. 


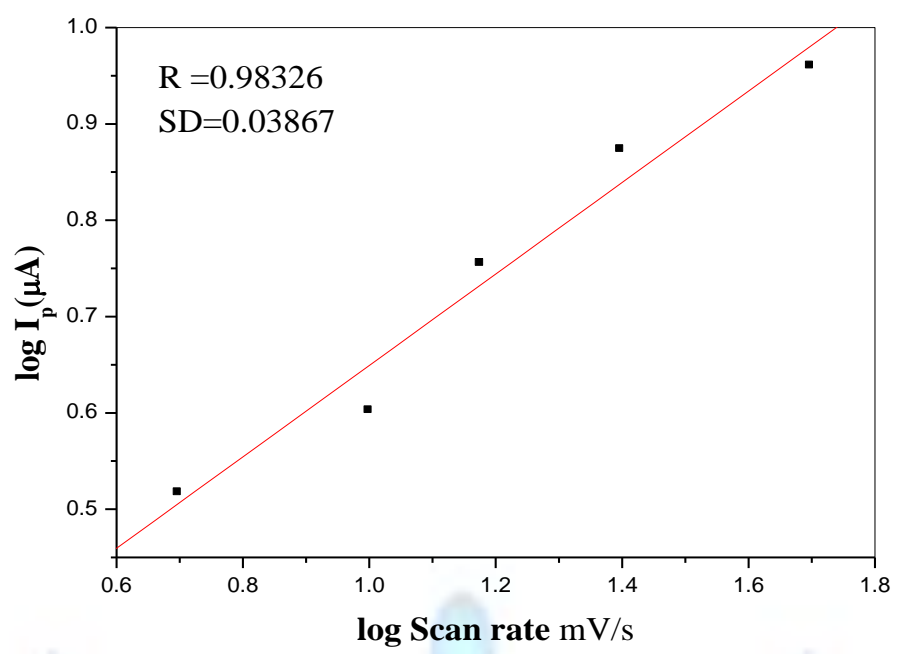

Fig. 7: Dependence of the peak current of $2 \times 10^{-4} \mathrm{~mol} \mathrm{dm}^{-3}$ trichloroacetic acid on scan rate in sodium nitrate $(\mathrm{pH}=6.0)$, using pt electrode with correlation value 0.98 and Standard deviation 0.0386 .

\subsection{Effect of accumulation potential and deposition time}

Tha accumulation potential and deposition time have no effect on the peak current of $\left(5 \times 10^{-4} \mathrm{~mol} \mathrm{dm}^{-3}\right)$ of trichloroacetic acid in sodium nitrate buffer $(\mathrm{pH}=6.0)$ was examined.

\subsection{Calibration curve}

The influence of trichloroacetic acid concentration on the peak current was studied over the range $\left(1 \times 10^{-6}-1 \times 10^{-4} \mathrm{~mol}\right.$ $\mathrm{dm}^{-3}$ ) in sodium nitrate $(\mathrm{pH}=6.0)$." Figure 8" shows a typical linear sweep voltammograms for different concentrations of trichloroacetic acid from $6 \times 10^{-5}$ to $6 \times 10^{-4} \mathrm{~mol} \mathrm{dm}^{-3}$ sodium nitrate $(\mathrm{pH}=6.0)$ at scan rate $50 \mathrm{mV} / \mathrm{s}$.

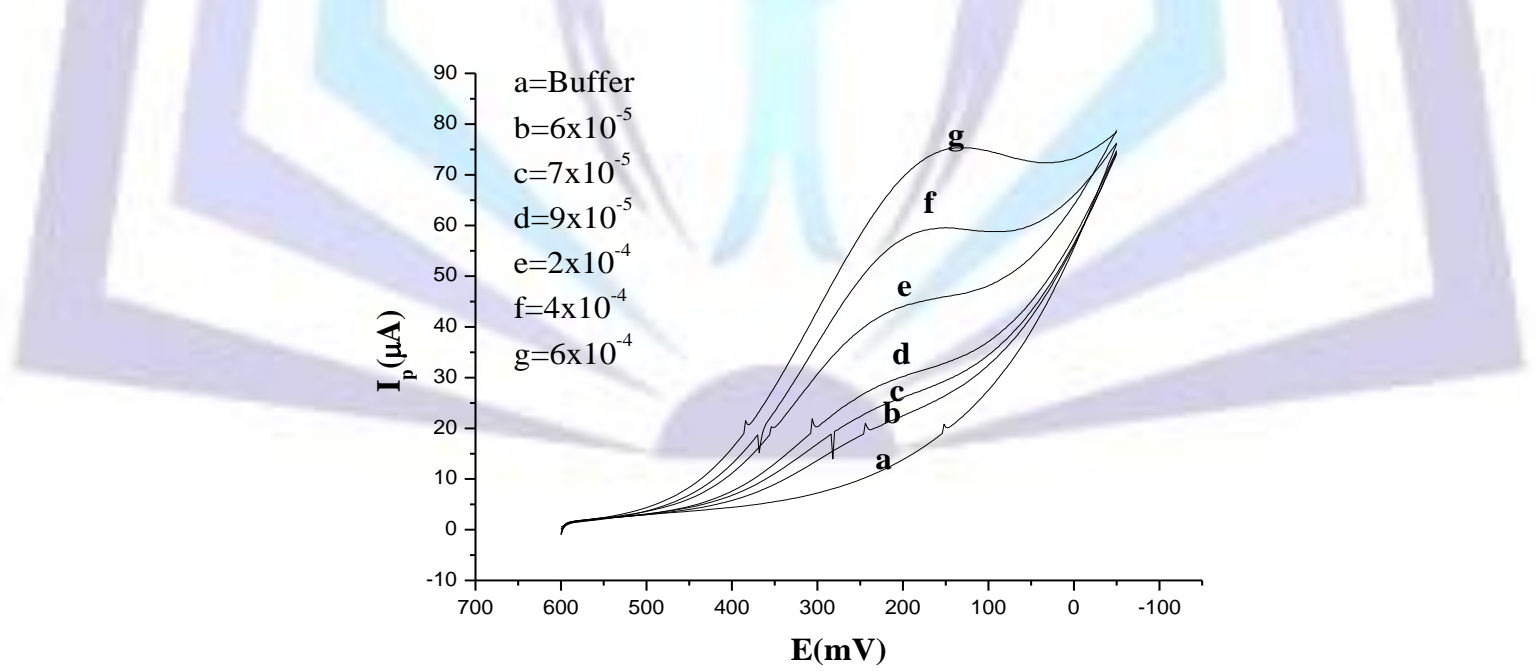

Fig.8: Linear sweep Voltammograms for different concentrations of trichloroacetic acid under the conditions of sodium nitrate $(\mathrm{pH}=6.0)$ of concentration $0.01 \mathrm{~mol} \mathrm{dm}^{-3}$ using Pt electrode at scan rate $50 \mathrm{mV} / \mathrm{s}$.

In which an increase in the peak current can be observed with increasing the concentration.

The calibration curve which indicates a linear dependence of the peak current on the concentration of the trichloroacetic acid with correlation value 0.99 and stander deviation 0.59 as shown in "figure 9". 


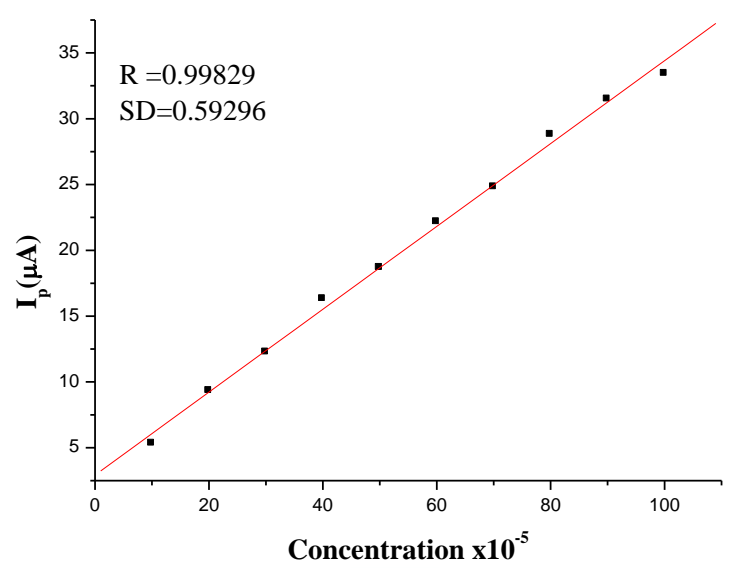

Fig. 9: Calibration Curve of trichloroacetic acid in sodium nitrate buffer $(\mathrm{pH}=6.0)$ using Pt electrode with correlation value 0.998 and Standard deviation 0.59 .

\subsection{Reproducibility}

The reproducibility of the results was examined by successive six measurements for $6 \times 10^{-4} \mathrm{~mol} \mathrm{dm}^{-3}$ of tichloroacetic acid at $50 \mathrm{mV} / \mathrm{s}$ scan rate in sodium nitrate $(\mathrm{pH}=6.0)$. The sensitivity of the linear sweep voltammetric analysis was proved by the good reproducibility of results illustrated in "figure 10".
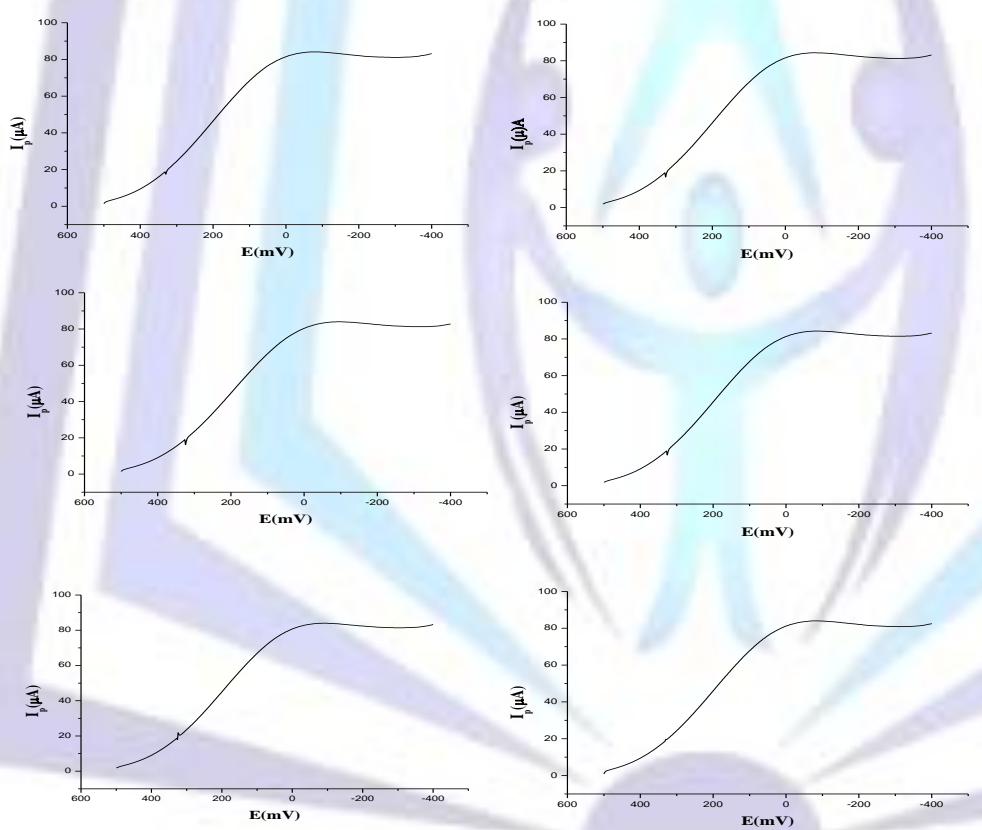

Fig. 10: Typical voltammograms for direct measurements of $6 \times 10-4 \mathrm{~mol} \mathrm{dm-3} \mathrm{trichloroacetic} \mathrm{acid} \mathrm{in} \mathrm{sodium}$ nitrate $(\mathrm{pH}=6.0) 50 \mathrm{mV} / \mathrm{s}$ using pt as electrode.

The statistics of the reproducibility data of trichloroacetic acid showed in "table 1".

\begin{tabular}{|c|c|c|c|c|c|c|}
\hline No. & mean & SD & SE & Min. & Max. & Range \\
\hline 6 & 25.46 & 0.27487 & 0.09718 & 24.78 & 25.4 & 0.62 \\
\hline
\end{tabular}




\subsection{Effect of interferences}

The interference problems in stripping analysis include adsorption of organic substances on the electrode and overlapping peaks. So the effect of phenols such as Hydroqunion and Catechol and metal such as $\mathrm{cd}^{+2}$ on the peak current of $5 \times 10^{-4} \mathrm{~mol} \mathrm{dm}^{-3}$ trichloroacetic acid was studied. That is illustrated in "table 2 ".

\begin{tabular}{|c|c|c|}
\hline Interferant & Conc. $\mathrm{mol} \mathrm{dm}^{-3}$ & Value $\%$ \\
\hline \multirow{3}{*}{ Hydroqunion } & $1 \times 10^{-4}$ & No effect \\
\hline & $5 \times 10^{-4}$ & No effect \\
\hline & $1 \times 10^{-3}$ & No effect \\
\hline \multirow{3}{*}{ Catechol } & $1 \times 10^{-4}$ & No effect \\
\hline & $5 \times 10^{-4}$ & No effect \\
\hline & $1 \times 10^{-3}$ & No effect \\
\hline \multirow{3}{*}{$\mathrm{Cd}^{+2}$} & $1 \times 10^{-4}$ & No effect \\
\hline & $5 \times 10^{-4}$ & 2.4 \\
\hline & $1 \times 10^{-3}$ & 3.2 \\
\hline
\end{tabular}

\section{Comparison between the present work and other work with the same and different techniques.}

The detection limit of the current method is lower than detected by L.Altamar ${ }^{(1)}$ and B.Liu ${ }^{(14)}$ that needs high cost and huge equipments and materials. On other hand amperometric technique can't detect (TCA) ${ }^{(7)}$.While in the present work, we used platinum electrode which is economic, easily prepared, rabidly and with high sensitive that can be showed in (table3).

"Table 3" showed the Comparison between the present work and other work with the same and different techniques.

\begin{tabular}{|c|c|l|}
\hline Electrode used & $\begin{array}{c}\text { Detection } \\
\text { limit }\end{array}$ & Reference \\
\hline $\begin{array}{c}\text { Multi wall carbon } \\
\text { nanotubes } \\
\text { (Modified electrode) }\end{array}$ & $5.0 \times 10^{-6}$ & Ref (1) \\
\hline $\begin{array}{c}\mathrm{C}_{60} \text {-[dimethyl-(b- } \\
\text { cyclodextrin) }]_{2} \text { and nafion } \\
\text { chemically } \\
\text { modified electrode }\end{array}$ & $4.0 \times 10^{-5}$ & Ref(14) \\
\hline $\begin{array}{c}\text { Amperometric technique } \\
\text { Notected }\end{array}$ & Ref(7) \\
\hline Platinum elrctrod & $4.0 \times 10^{-6}$ & Present \\
work
\end{tabular}




\section{Conclusion}

Linear sweep voltammetric measurements was applied using platinum electrode in sodium nitrate $0.01 \mathrm{M}(\mathrm{pH}=6.0)$ and $50 \mathrm{mV} / \mathrm{s}$ scan rate to determine trichloroacetic acid with detection limit of $4 \times 10^{-6} \mathrm{~mol} \mathrm{dm}^{-3}$. Comparison the results obtained in the present study with other published works was described in table (3). From which, the present work using the suggested procedures can be used to detect the studied compounds with accurate, easily, rabidly,cheap and with low detection limit than other methods and tchniques.

\section{References}

[1] Liu. B, Hu.x, Deng.Y, Yang. S and Cheng Sun, Electrochemistry Communications, 12, (2010) 1395-1397.

[2] Punyapalakul. P, Soonglerdsongpha.S, Kanlayaprasit.C , Ngamcharussrivichai.C and S. Khaodhiar, Journal of Hazardous Materials, 171, (2009) 491-499.

[3] Korshin. G.V. and Jensen. M. D, Electrochimica Acta, 47, (2001) 747-751.

[4] Li .Y.P, Cao. H.B and Y,Zhang, Chemosphere, 63, (2006) 359-364.

[5] Loos. R and Barcelo. D, Journal of Chromatography A, 938, (2001) 45-55.

[6] Altamar.L, Fernandez.L., Borras.C, Mostany.J, Carrero. H and Scharifker. B, Sensors and Actuators B, 146, (2010) 103-110.

[7] Carrero. H and Rusling.J.F, Talanta, 48, (1999) 711-718.

[8] Alhooshani.K, Basheer.C, Kaur.J Gjelstad,A, Rasmussen. K. E, Bjergaard. S.P. and Lee.H.K., Talanta, 86, (2011) $109-113$.

[9] Korshin. G. V and Jensen. M. D, Electrochimica Acta, 47, (2001) 747-751.

[10] Esclapez.M.D, Garcia.M.I.D, Saez.V, Tudela.I,.J.M.Pérez, Garcia.J.G and Bonete.P, Electrochimica Acta, 56, (2011) $8138-8146$

[11] Altamar. L, Fernandez. L, Borras.C, Mostany.J, Carrero.H and Scharifker.B, Sensors and Actuators B, 146, (2010) 103-110.

[12] Xu. Y. H, Zhang.H, Chu.C.P and Ma.C.A, Journal of Electroanalytical Chemistry, 664, (2012) 39-45.

[13] Wei.M, Li.M, Li. N, Gu.Zand Zhou.X, Talanta, 53, (2001) 1045-1052. 